\title{
PENGARUH KOMUNIKASI DAN GAYA KEPEMIMPINAN TERHADAP KINERJA PEGAWAI PADA PT.VISIONET DATA INTERNASIONAL CABANG KARAWACI
}

\author{
Ading Sunarto \\ Dosen Prodi Manajemen Universitas Pamulang \\ email : dosen02153@unpam.ac.id
}

\begin{abstract}
ABSTRAK
Penelitian ini mempunyai tujuan untuk melihat pengaruh komunikasi dan gaya kepemimpinan terhadap kinerja pegawai pada PT.Visionet Data Internasional Cabang Karawaci dan untuk melihat bagaimana kinerja karayawan pada PT.Visionet Data Internasional Cabang Karawaci. Penelitian ini berjenis penelitian kuantitatif dengan pendekatan deskriptif, merupakan penelitian yang berupa data-data deskriptif yaitu kata-kata tertulis ataupun lisan dari informan penelitian serta perilaku obyek penelitian yang dilakukan penelitian.. Hasil yang didapatkan dari penelitian dibawah ini memperlihatkan bahwa komunikasi $\left(\mathrm{X}_{1}\right)$ dan gaya kepemimpinan $\left(\mathrm{X}_{2}\right)$ memeiliki pengaruh positif serta signifikan terhadap kinerja pegawai, dengan didapatkan persamaan regresinya yaitu $Y=16,610+0,264 X_{1}+0,323 X_{2}$. Nilai koefisien determinasi atau kontribusi pengaruh secara bersama sama dengan nilai 0,258 atau $25,8 \%$ sementara sisanya senilai $74,2 \%$ dipengaruhi adanya faktor lain yang tidak diteliti. Uji hipotesis didapatkan nilai $F$ hitung $>F_{\text {tabel }}$ atau $(13,007>3,12)$, hal ini menjadi lebih kuat penelitiannya dengan $\rho$ value < Sig.0,05 atau $(0,000<0,05)$. Oleh karenanya $\mathrm{H}_{0}$ tdak diterima dan $\mathrm{H}_{3}$ dapat diterima. Hal ini berarti bahwa ada pengaruh yang positif serta signifikan secara bersama-sama antara komunikasi dan gaya kepemimpinan terhadap kinerja pegawai pada PT.Visionet Data Internasional Cabang Karawaci.
\end{abstract}

Kata Kunci: Komunikasi, Gaya Kepemimpinan, dan Kinerja Karyawan.

\section{ABSTRACT}

This study aims to see the influence of communication and leadership style on the performance of employees at PT. Visionet Data Internasional, Karawaci Branch and to see how the performance of employees at PT. Visionet Data Internasional, Karawaci Branch. This research is a quantitative research with a descriptive approach, which is a research in the form of descriptive data, namely written or spoken words from research informants as well as the behavior of the research object carried out by the research. The results obtained from the research below show that communication (X1) and leadership style (X2) has a positive and significant influence on employee performance, by obtaining the regression equation, namely $Y$ $=16.610+0.264 X 1+0.323 X 2$. The coefficient of determination or the contribution of influence is the same as the value of 0.258 or $25.8 \%$ while the remaining $74.2 \%$ is influenced by other factors not examined. Hypothesis testing obtained the value of $F$ count $>$ Ftable or (13.007> 3.12), this is a stronger research with $\rho$ value $<$ Sig. 0.05 or $(0.000<0.05)$. Therefore HO is not accepted and $\mathrm{H} 3$ is acceptable. This means that there is a positive and significant influence jointly between communication and leadership style on employee performance at PT.Visionet Data Internasional, Karawaci Branch.

Keywords: Communication, Leadership Style, and Employee Performance. 
JRNAL ПMПAH

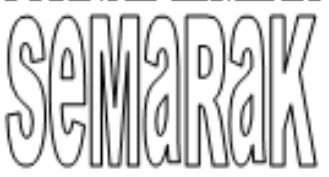

P-ISSN 2615-6849, E-ISSN 2622-3686

Jurnal Semarak,Vol.4,No.2,Juni 2021, Hal (105-118)

@Prodi Manajemen Fakultas Ekonomi Universitas Pamulang

\section{PENDAHULUAN}

\subsection{Latar Belakang}

Bagi setiap organisasi, meningkatkan daya tahan untuk dapat tetap bersaing dalam dunia bisnis yang semakin penuh kompetisi adalah merupakan suatu kebutuhan. Namun, cukup dengan daya tahan saja sebetulnya tidaklah cukup. Agar tetap kompetitif diperlukan perbaikan kinerja secara berkelanjutan untuk meningkatkan daya saing, meningkatkan Competitive adventage, agar dapat memiliki keunggulan dalam kompetisi.

Untuk mengetahui apakah dalam proses pencapaian tujuan organisasi bisa berjalan dengan baik, maka organisasi perlu untuk melakukan evaluasi kinerja. Dalam bidang SDM maka sebuah organisasi perlu untuk memperhatikan kinerja pegawainya. Menurut Benardin dan Russel (2014:270) kinerja yaitu "Suatu hasil kerja yang dihasilkan oleh seorang pegawai diartikan untuk mencapai tujuan yang diharapkan". Kinerja merupakan hasil yang di hasilkan oleh fungsi pekerjaan tertentu ataupun suatu kegiatan pada pekerjaan tertentu selama periode. Mangkunegara (2015:9) mengatakan kinerja karyawan (prestasi kerja) ialah hasil dari kerja secara kualitas \& kuantitas yang dicapai oleh seseorang karyawan dalam melaksanakan tugasnya sesuai dengan tanggungjawab yang diberikan olehnya. Oleh sebab itu kesimpulannya bahwa kinerja SDM merupakan prestasi kerja atau output atau hasil kerja baik berkualitas ataupun berkuantitas yang diraih SDM per periode tertentu dalam melaksanakan tugas kerjanya sesuai dengan tanggungjawab yang diberikan kepadanya.

Berdasarkan hasil pengamatan yang penulis lakukan di PT. Visionet Data Internasional Cabang Karawaci sering terjadi kesalahpahaman informasi antara pimpinan dan karyawan. Dikarenakan informasi yang disampaikan oleh pimpinan tidak secara utuh sampai kepada karyawan lini bawah . Jika ditinjau dari sedikitnya saluran komunikasi yang benar antara pimpinan \& karyawan yang mengakibatkan atasan mendapatkan kesusahan dalam memahami kemauan serta kebutuhan pegawainya begitupun sebaliknya. Saluran komunikasi yang telah dilaksanakan di PT.Visionet Data Internasional Cabang Karawaci dapat diketahui pada tabel di bawah ini.

Table I

Bentuk Komunikasi didalam PT. Visionet Data Internasional Cabang Karawaci

\begin{tabular}{|c|c|c|c|}
\hline No & $\begin{array}{l}\text { Jenis } \\
\text { Komun } \\
\text { ikasi }\end{array}$ & $\begin{array}{l}\text { Freku } \\
\text { ensi } \\
\text { Perte } \\
\text { muan } \\
\end{array}$ & Keterangan \\
\hline 1 & $\begin{array}{l}\text { Antara } \\
\text { Genera } \\
l \\
\text { Manag } \\
\text { er } \\
\text { dengan } \\
\text { seluruh } \\
\text { Kepala } \\
\text { Unit } \\
\end{array}$ & $\begin{array}{l}1 \\
\text { bulan } \\
\text { sekali }\end{array}$ & $\begin{array}{l}\text { a. Evaluasi } \\
\text { hasil kerja } \\
\text { perusahaan } \\
\text { dalam sebulan. } \\
\text { b. Membuat } \\
\text { rencana } \\
\text { program kerja 1 } \\
\text { bulan } \\
\text { selanjutnya. }\end{array}$ \\
\hline 2 & $\begin{array}{l}\text { Daily } \\
\text { Breafin } \\
g \text { antara } \\
\text { Kepala } \\
\text { Unit } \\
\text { dengan } \\
\text { karyaw } \\
\text { an }\end{array}$ & $\begin{array}{l}\text { Setiap } \\
\text { hari }\end{array}$ & $\begin{array}{l}\text { a. Mengupas } \\
\text { pekerjaan rutin } \\
\text { setiap hari. } \\
\text { b. Pemberian } \\
\text { petunjuk } \\
\text { didalam } \\
\text { pelaksanaan \& } \\
\text { tugas } \\
\text { tanggung jawab } \\
\text { ataupun } \\
\text { masalah- } \\
\text { masalah yang } \\
\text { sedang } \\
\text { dihadapi. }\end{array}$ \\
\hline
\end{tabular}

Menurut data table tersebut, dapat dikatakan bahwa belum pernah diadakan rapat atau meeting antara atasan atau manajemen dengan seluruh pegawai di PT.Visionet Data Internasional Cabang Karawaci. Salah satu sampelnya yaitu belum pernah dibuat acara General Staff Meeting uguna melihat keluh 
JRNAL ПMПAH

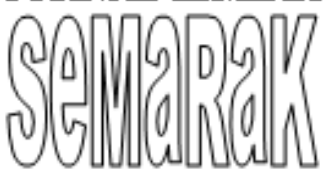

P-ISSN 2615-6849, E-ISSN 2622-3686

Jurnal Semarak,Vol.4,No.2,Juni 2021, Hal (105-118)

@Prodi Manajemen Fakultas Ekonomi Universitas Pamulang

kesah, kebutuhan masing-masing pegawai, kritik ataupun saran dari pegawai kepada pimpinannya. Base on hal itu, ini butuh dilakukan penelitian atas pengaruh komunikasi \& gaya kepemimpinan terhadap kinerja pegawai PT.Visionet Data International Cabang Karawaci.

Penyelesaian permasalahan anggota didalam organisasi perusahaan memusatkan komunikasi mereka kepada penyelesaian masalah para pegawai secara bersama. Sikap serta perilaku memperlihatkan perhatian serta pengertian kepada anggota lain, menganggap pegawai lain sebagai teman serta tidak menekankan kepada kedudukan \& kekuasaan. Suasana komunikasi meliputi kepuasan anggota organisasi atas informasi yang ada dan tersedia. Rasa puas dalam penjelasan ini memperlihatkan kepada bagaimana bagusnya informasi yang tersedia mencukupi syaratsyarat permintaan pegawai organisasi akan tuntutan pekerjaan. Informasi datangnya dari siapa, bagaiamana caranya supaya bisa disebarluaskan, bagaimana dapat diterima, direspon serta respon apa terhadap orang yang menerimanya. Suasana komunikasi yang suportif akan berdampak pada meningkatnya perasaan karyawan bahwa karyawan adalah sebagian dari organisasi, menimbulkan perasaan bahwa diri mereka berharga. Hal ini akan sangat strong mempengaruhi reward diri (self esteem), komitmen kepada perusahaan serta tingkah laku yang kooperatif.

Timbulnya masalah-masalah di antara karyawan perusahaan juga disebabkan sebab belum adanya trust. Atasan dan karyawan saling tidak percaya atas kinerja individu. Masalah-masalah penyaluran reward yang masih dinilai kurang adil oleh karyawan. Kaitannya dengan decision making bersama, karyawan mendapatkan kesusahan dalam berkomit pada kesepakatan yang sudah ditetapkan, meskipun pada akhirnya karyawan akan patuh apapun instruksi dari atasan, namun perbuatan tersebut bukan indikasi bahwa karyawan peduli, namun malah sebaliknya yaitu sikap yang enggan mau tahu. Informasi yang diperoleh maupun disampaikan mendapatkan penyaringan serta tidak disiplin waktu akibatnya membuat karyawan menjadi tidak puas. Karyawan lebih open kepada sesama rekan kerja dibandingkan dengan atasan tentang kemauan atau harapan yang akan didapatkan untuk pribadi maupun perusahaan.

Lemahnya pengawasan pada setiap unit program tidak lepas dari peran seorang pemimpin. Gaya kepemimpinan memfokuskan pada tingkah laku maupun karakteristik atasan saat mengarahkan, memberikan dorongan, membimbing, serta mengelola sekelompok karyawan. Atasan yag hebat adalah pemimpin yang bisa menginspirasi gerakan politik serta perubahan sosial. Pemimpin juga dapat memberikan dorongan orang lain agar dapat tampil, berkreasi, serta menemukan sesuatu yang baru dan inovatif. Gaya kepemimpinan yang pas akan meningkatkan semangat serta dorongan pegawai dalam bekerja yang dapat meningkatkan hasil kerjanya.

Semua perusahaan tentunya mengharapkan supaya visi dan misinya dapat tercapai, faktor penentunya ialah komunikasi serta gaya kepemimpinan, hal ini mempunyai pengaruh terhadap kinerja pegawai dalam organisasi, tentu saja organisasi yang dimaksud yaitu seluruh organisasi yang mempunyai SDM, tidak terkecuali adalah PT.Visionet Data International Cabang Karawaci. PT.Visionet Data International merupakan organisasi total IT Managed Services yang ada di negara Indonesia. Memberikan cakupan nasional di 150 titik yang terbesar di seluruh wilayah Indonesia. Mempunyai sertifikat "ISO 9001: 2008, ISO 27001: 2013" serta PCI DSS, fokus perusahaan ialah untuk memenuhi kebutuhan serta mensupport konsumen dalam mengoperasikan IT dan memastikan hasil kerja maksimal serta keandalan dan efektivitas pelanggan PT.Visionet Data International memberikan penawaran outsourcing yang terhubung dari layanan operasi data center agar berbagi 
JRNAL ПMПAH

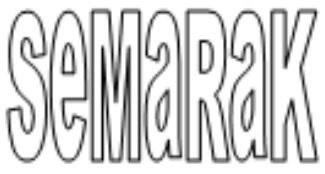

P-ISSN 2615-6849, E-ISSN 2622-3686

Jurnal Semarak,Vol.4,No.2,Juni 2021, Hal (105-118)

@Prodi Manajemen Fakultas Ekonomi Universitas Pamulang

aplikasi business IT hampir di seluruh bagian Indonesia.

Perusahaan

sangat

mempertimbangkan faktor komunikasi dan gaya kepemimpinan, sebab seluruh lini didalam perusahaan ini saling berhubungan dan sustainable, ditambahkan pula perusahaan sedang menghadapi era Revolusi Industri 4.0 serta MEA dimana organisasi ini harus dapat menambah kualitas outputnya supaya dapat berkompetisi dengan orgsnisasi lain yang memiliki orientasi tujuan yang sama, PT.Visionet Data Internasional juga membutuhkan hasil kerja pegawai yang baik untuk bisa menghasilkan output yang mempunyai kualitas, oleh sebab itu dapat berkompetisi dengan perusahaan lainnya yang sama jenisnya.

Atas permasalahan-permasalahan tersebut peneliti mempunyai pandangan terhadap permasalahan yang terjadi dikarenakan masih sedikitnya motivasi maupun pengarahan oleh pimpinan organisasi tersebut ataupun sedikitnya kesadaran dalam diri pribadi pegawai dalam menjalankan tugastugas yang di embannya. Melalui deskripsi permasalahan tersebut, oleh sebab itu peneliti beranggapan sangat perlu mengeksplorasi permasalahan tersebut melalui penelitian ini. Dengan melihat dari latar belakang permasalahan yang penulis deskripsikan di atas maka judul yang ingin peneliti ambil yaitu "Pengaruh Komunikasi dan Gaya Kepemimpinan Terhadap Kinerja Pegawai pada adalah PT.Visionet Data Internasional Cabang Karawaci",

\subsection{Rumusan Permasalahan}

Rumusan permasalahan penelitian yang penulis sampaikan sebagai berikut:

1. Apakah ada pengaruh yang positif serta signifikan Komunikasi terhadap Kinerja pegawai pada PT.Visionet Data Internasional Cabang Karawaci ?

2. Adakah pengaruh yang positif serta signifikan gaya kepemimpinan terhadap Kinerja pegawai pada PT.Visionet Data Internasional Cabang Karawaci ?

3. Adakah pengaruh yang yang positif serta signifikan diantara komunikasi \& gaya kepemimpinan secara simultan terhadap Kinerja karyawan PT.Visionet Data Internasional Cabang Karawaci ?

\subsection{Tujuan Penelitian}

Maksud dan tujuan dari penelitian ini sebagai berikut:

1. Untuk melihat dan menemukan apakah terdapat pengaruh komunikasi terhadap kinerja pegawai PT.Visionet Data International Cabang Karawaci.

2. Untuk melihat dan menemukan apakah terdapat pengaruh gaya kepemimpinan terhadap pegawai PT.Visionet Data Internasional Cabang Karawaci.

3. Untuk melihat dan menemukan apakah terdapat pengaruh komunikasi dan gaya kepemimpinan secara bersama sama terhadap pegawai PT.Visionet Data Internasional Cabang Karawaci.

\section{TINJAUAN PUSTAKA}

\subsection{Komunikasi}

Mulyana (2010: 62) menyatakan bahwa : "Dalam komunikasi yang melibatkan 2 orang, komunikasi berlangsung jika adanya kesamaan maksud dan arti. sesuai dengan definisi tersebut pada dasarnya sesorang melakukan komunikasi yaitu untuk mencapai kesamaan arti antara manusia yang terlibat didalamnya didalam komunikasi yang telah terjadi, dimana kesepahaman yang ada didalam benak komunikator (penyampai pesan) dengan komunikan (penerima pesan) tentang pesan yang akan disampaikan haruslah sama supaya apa yang komunikator maksud juga dapat dipahami dengan baik oleh komunikan supaya komunikasi berjalan baik dan efektif'. Handoko (2016:270) menyatakan bahwa : "Komunikasi merupakan proses pemindahan pengertian dalam bentuk gagasan atau informasi dari seseorang kepada orang 
JRNAL ПММАH

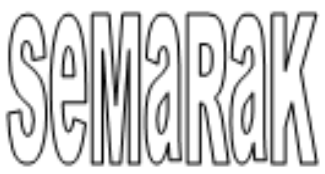

P-ISSN 2615-6849, E-ISSN 2622-3686

Jurnal Semarak,Vol.4,No.2,Juni 2021, Hal (105-118)

@Prodi Manajemen Fakultas Ekonomi Universitas Pamulang

lain". Sedangkan Siagian (2015:309), menyatakan bahwa "Proses komunikasi menyangkut hal-hal sebagai berikut":

1. "Adanya 2 pihak yang terlibat, yaitu subyek serta obyek komunikasi. Subyek yaitu sumber lalu obyek sebagai sasaran komunikasi".

2. “Adanya "pesan" yang akan disampaikan oleh subyek kepada obyek".

3. "Pemilihan cara / metode yang dipakai oleh subyek untuk menyampaikan pesan, lisan ataupun tertulis, melalui alat penyampaiannya".

4. "Pemahaman metode penyampaian pesan oleh obyek sehingga pesan diterima dalam bentuk yang diinginkan oleh subyek".

5. "Penerimaan oleh obyek".

6. "Umpan balik dari obyek ke subyek".

Menurut Nurjaman \& Umam, (2012:36-38), menyatakan bahwa "Supaya suatu proses komunikasi dapat lebih efektif, dibutuhkan unsur-unsur yang paling mendasar sebagai syarat-syarat terjadinya komunikasi". Ada tiga unsur wajib yang perlu dipenuhi didalam sebuah tahap-tahap komunikasi, yaitu" :

1. "Komunikator : merupakan orang yang menyatakan pesan kepada komunikan yang bisa berupa perseorangan ataupun kelompok".

2. "Komunikan : yaitu orang yang menerima pesan dari komunikator".

3. "Saluran atau media : yaitu jalan yang dilalui oleh isi pernyataan komunikator kepada komunikan yang dipakai oleh pengirim pesan".

\subsection{Gaya Kepemimpinan}

Menurut Edison (2016), menyatakan bahwa "Gaya kepemimpinan yaitu cara atasan berperilaku, bertindak serta bagaimana merkea dapat mempengaruhi bawahannya dalam upaya mencapai tujuan-tujuan tertentu". Para ahli menilai bahwa gaya kepemimpinan setiap individu mempunyai perbedaan. Kepemimpinan sendiri adalah tindakan yang mempengaruhi orang lain atau anggotanya suopaya dapat bekerjasama untuk mencapai tujuan yang telah ditargetkan.

Tatanan dalam kehidupan sosial umat manusia dibutuhkan tata kelola yang baik, sumber manusia yang berkualitas sangat diperlukan dalam hal ini. Sumber daya harus memiliki jiwa memimpin, paling tidak untuk memimpin dirinya sendiri dalam kehidupan sehari-hari. Dengan memiliki jiwa pemimpin, individu dapat mengelola dirinya sendiri, kolompok serta lingkunganya dengan baik. Menurut Subkhi dan Jauhar (2013:145), menyatakan bahwa: "Dalam menyelesaikan permasalahan seorang pemimpin diperlukan untuk mengambil keputusan supaya masalah dapat terselesaikan".

Menurut Edison (2016:43), menyatakan bahwa "Beberapa indikator dalam mengukur gaya kepemimpinan menurut yaitu sebagai berikut":

1. "Mempunyai strategi yang jelas \& dikomunikasikan dengan baik, Atasan memiliki strategi yang jelas dan realistis dan bawahan percaya terhadap atasan dalam melakukan perubahan ke arah yang lebih baik lagi".

2. "Mempunyai tingkat kepedulian kepada bawahan \& lingkungannya, dapat mememberikan perhatian serta motivasi kerja bawahan serta memperhatikan lingkungan dan kenyamanan dalam bekerja".

3. "Merangsang bawahan, Merangsang anggota untuk membekali diri dengan pengetahuan dan keahlian dalam usaha meningkatkan keahlian dan kompetensinya".

4. "Menjaga kekompakan team, dapat mengajak bawahan agar bekerja dalam team yang solid dan harmonis".

5. "Menghormati serta menghargai perbedaan \& keyakinan, Menghargai setiap perbedaan pendapat untuk tujuan lebih baik lagi”. 
JRNAL ПMПAH

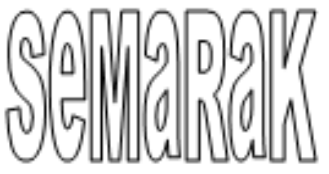

P-ISSN 2615-6849, E-ISSN 2622-3686

Jurnal Semarak,Vol.4,No.2,Juni 2021, Hal (105-118)

@ Prodi Manajemen Fakultas Ekonomi Universitas Pamulang

\subsection{Kinerja}

Fahmi (2010:2), menjelasakan bahwa "Kinerja merupakan hasil yang didapatkan oleh suatu organisasi baik organisasi tersebut bersifat profit oriented dan non profit oriented yang dihasilkan selama beberapa periode". Dengan lebih jelas Amstron \& Baron menyatakan bahwa "Kinerja merupakan hasil pekerjaan yang memiliki kaitan kuat dengan tujuan strategis organisasi, kepuasan konsumen dan memberikan kontribusi ekonomi". Sementara itu Mangkunegara (2015:67) menjelaskan bahwa "Pengertian kinerja (prestasi kerja) merupakan hasil kerja secara kualitas \& kuantitas yang dicapai oleh seorang karyawan didalam menjalankan tugas pekerjaannya sesuai dengan tanggung jawab yang diberikan kepadanya". Kemudian Simanjutak dalam Widodo (2015:131) menjelasakan bahwasanya "Kinerja yaitu tingkatan pecapaian hasil atas tugas tertentu yang dijalankannya, atau dengan kata lain bahwa kinerja merupakan tingkat pencapaian atau hasil kerja seseorang dari sasaran yang harus dicapai atau tugas yang harus dilaksanakan dalam kurun waktu tertentu".

Edy Sutrisno (2014:153)

menjelaskaan bahwa "Faktor yang mempengaruhi kinerja ada 2 faktor yang mempengaruhi kinerja yaitu, faktor disiplin individu serta lingkungan, faktor-faktor individu tersebut adalah sebagai berikut":

1. "Usaha yang menunjukkan sejumlah sinergi fisik dan mental yang digunakan dalam menyelenggarakan gerakan tugas".

2. "Abilities, adalah sifat-sifat personal yang dibutuhkan dalam menjalankan suatu tugas. Dan pada umumnya orang percaya bahwa kinerja individu ialah fungsi gabungan dari 3 faktor, yaitu" :

a. Kompetensi, sifat \& keinginan seorang pegawai.

b. Ketepatan \& penerimaan atas penjelasanperanan seorang pegawai. c. Tingkat dorongan motivasi
kerja.
Pada dasarnya perpaduan ke-3 faktor tersebut sangat menentukan prestasil kerja yang dapat menentukan suatu kinerja dari setiap pegawai, karena setiap faktor mempunyai arti ataupun manfaat masingmasing bagi penentuan kinerja.

\subsection{Kerangka Berfikir}

Sugiyono (2017:60) menyatakan bahwa "Kerangka berpikir yang baik adalah kerangka berfikir yang dapat menjelaskan secara teoritis korelasi antar variabel yang akan diteliti. Sintesa mengenai hubungan variable tersebut, yang selanjutnya dipakai untuk merumuskan hipotesis".

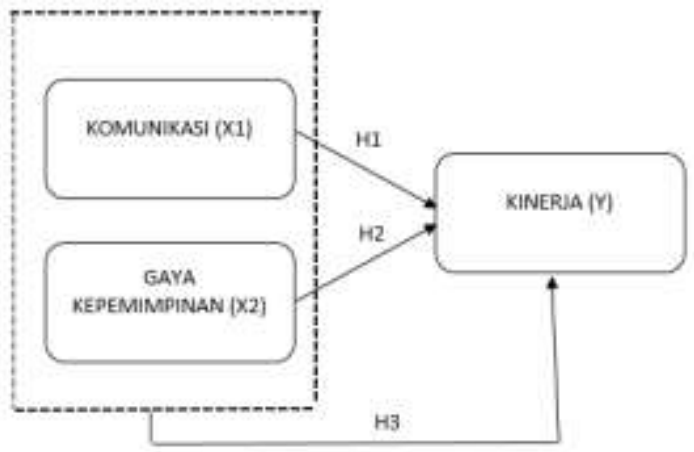

Gambar 1. Kerangka Pemikiran

\section{METODOLOGI PENELITIAN}

\subsection{Rancangan Penelitian}

Jenis penelitian yang penulis lakukan yaitu Kuantitatif dengan pendekatan assosiatif, menurut Sugiyono (2017:44) menjelaskan bahwasanya "Penelitian yang bertujuan untuk mengetahui pengaruh atau hubungan antara dua variabel atau lebih". Oleh karenanya penelitian assosiatif tersebut dapat diciptakan sebuah teori yang mempunyai fungsi untuk mendeskripsikan, memperkirakan serta pengontrol suatu gejala tempat dan waktu penelitian.

\subsection{Populasi dan Sampel Penelitian}

Menurut Sugiyono (2015:115), menyatakan bahwa "Populasi merupakan suatu wilayah generalisasi yang terdiri dari atas objek atau subjek yang mempunyai 
JRNAL ПMПAH

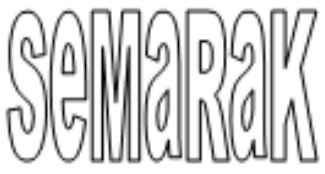

P-ISSN 2615-6849, E-ISSN 2622-3686

Jurnal Semarak,Vol.4,No.2,Juni 2021, Hal (105-118)

@ Prodi Manajemen Fakultas Ekonomi Universitas Pamulang

karakteristik dan kualitas tertentu yang ditetapkan oleh penulis untuk dipelajari dan kemudian ditarik kesimpulan". Populasi didalam penelitian ini yaitu semua karyawan PT.Visionet Data Internasional Cabang Karawaci sebanyak 78 orang.

Sampel didalam penelitian ini yaitu 78 orang karyawan. Oleh karena itu penulis gunakan sampel berupa sampel jenuh. Sugiyono (2015:68) menyatakan bahwa "Sampel jenuh adalah teknik penentuan sampel bila semua anggota populasi digunakan sebagai sampel".

\subsection{Metode Pengumpulan Data}

Pengumpulan data yaitu salah satu cara dalam memperoleh bahan-bahan informasi yang ingin dipakai dalam pengukuran variable. Sugiyono (2015:308), menyatakan bahwa "Metode pengumpulan data adalah cara ilmiah utuk mendapatkan data yang valid dengan tujuan dapat dibuktikan, dikembangkan suatu pengetahuan sehingga dapat digunakan memecahkan dan mengantisipasi masalah".

Didalam proses pengumpulan datadata didalam penelitian ini penulis memakai beberapa macam teknik metode pengumpulan data, dan tentunya hal ini disesuaikan dengan masalah yang akan penulis teliti. Data didalam penelitian ini dikumpulkan dengan menggunkan teknik diantaranya dengan observasi, penyebaran questioner, study kepustakaan dan pencarian sumber informasi berupa history perusahaan atau sejarah perusahaan, jumlah karyawan dan lain sebagainya.

\subsection{Metode Analysis Data}

Angka-angka yang bisa dihitung serta dapat diukur merupakan pengertian dari metode analisis kuantitatif dan pengolahan data dimetode ini dilakukan dengan beberapa tahap.

\subsubsection{Uji Statistik Deskriptif}

Menjelaskan secara statistik variabel-variabel yang diteliti adalah tujuan dari adanya uji statistic deskriptif. Menurut Ghozali (2016:47), menyatakan bahwa
"Statistik deskriptif menjelaskan bagaimana data dikategorikan menjadi sebuah kelompok-kelompok data yang lebih mudah dianalisis atau dibaca oleh pengguna informasi".

\subsubsection{Uji Asumsi Klasik}

Menentukan model regresi apakah model regresi layak untuk diteliti atau tidak adalah merupakan tujuan dari uji asumsi klasik. Didalam penelitian ini uji asumsi klasiknya yaitu : uji normalytas, uji multykolinearitas, uji autokorelasi dan uji heteroskedastysitas.

\subsubsection{Analisa Regresi Berganda}

Fungsi dari adanya regresi linear berganda adalah sebagai alat analysis pengolahan data, pemakaian regresi berganda karena dalam penelitian ini memakai 3 variable independen (lebih dari 1 variable bebas) terhadap satu variable terikat. Untuk mengetahui pengaruh Komunikasi (X1) dan Gaya Kepemimpinan (X2) terhadap Kinerja Karyawan (Y) maka digunakan nalysis regresi sederhana. Persamaan regresi linear sederhana dapat dicari dengan rumus:

$$
\mathrm{Y}=\mathrm{a}+\mathrm{b}_{1} \mathrm{X}_{1}+\mathrm{b}_{2} \mathrm{X}_{2}
$$
Sumber: Sugiyono (2017:277).

Keterangan:

$\mathrm{a}=$ Konstanta

$\mathrm{Y}=$ Variable terikat atau Kinerja

$\mathrm{b}_{1}=$ Koefisien regresi komunikasi

$\mathrm{b}_{2}=$ Koefisienregresigayakepemimpinan

$\mathrm{X}_{1}=$ Komunikasi

$\mathrm{X}_{2}=$ Gaya Kepemimpinan

\section{Uji Hipotesis}

\section{Uji t}

Pengaruh dari masing-masing variable bebas secara sebagian (individu) diukur dengan memakai uji statistic (t). "Uji statistik (t) pada dasarnya menunjukkan sejauh mana pengaruh satu variabel independen secara individu dalam menerangkan variasi variabel dependen (Ghozali, 2016 : 35)". 
Melalui uji t pada tingkat keyakinan 95\%, maka pengujian dilakukan dengan persyaratan sebagai berikut:

1) Bila hasil signifikansi $<0,05$, atau $t$ hitung > t table maka diduga ada pengaruh antara variable $\mathrm{X}$ terhadap variable Y.

2) Bila hasil signifikansi $>0.05$, atau $t$ hitung $<\mathrm{t}$ table maka diduga tidak terdapat pengaruh antara variable $\mathrm{X}$ terhadap variable Y.

\section{Uji Goodness of Fit (Uji F dan $\mathbf{R}^{2}$ )}

Dalam mengukur ketepatan sample antara keinginan dengan yang sebenarnya maka menggunakan uji sebagai berikut :

A. Uji F (Uji secara bersama-sama atau Simultan)

Untuk mengetahui ada atau tidaknya pengaruh keseluruhan variable bebas dalam menjelaskan variable terikat secara bersama-sama (simultan), maka digunakan uji simultan (Uji F). Nilai Ftest dapat memperlihatkan Uji $\mathrm{F}$ yang ingin kita ketahui. Nilai F didalam penelitian ini digunakan tingkat signifikan 0,05 dengan kriteria pengujian yang digunakan yaitu:

1) Bila hasil signifikansi dari $F<0,05$ atau $\mathrm{F}_{\text {hitung }}>\mathrm{F}_{\text {tabel }}$ menunjukkan bahwa uji model ini cocok untuk dipakai pada penelitian.

2) Apabila hasil signifikansi $F>0,05$ atau $\mathrm{F}_{\text {hitung }}<\mathrm{F}_{\text {tabel }}$ menunjukkan bahwa uji model ini tidak cocok untuk dipakai pada penelitian

B. Koefisien Determinasi $\left(\mathrm{R}^{2}\right)$

Ghozali (2016 : 45), menyatakan bahwa "koefisien determinasi $\left(\mathrm{R}^{2}\right)$ digunakan untuk mengukur sejauh mana kemampuan model dalam menerangkan variasi variabel dependen". Uji $\mathrm{R}^{2}$ dipakai untuk melihat besarnya kemampuan vaiabel independen dalam menjelaskan variasi variable dependen dan nilai $\mathrm{R}^{2}$ yaitu antara 0
\& 1. Semakin terbatas kemampuan variable-variable bebas dalam menjelaskan variable terikatnya artinya semakin kecil nilai koefisien determinasi $\left(\mathrm{R}^{2}\right)$. Dan "jika nilai $\mathrm{R}^{2}$ yang mendekati satu (1) berarti variabel-variabel independen memberikan hampir semua informasi yang dibutuhkan untuk memprediksi variasi variabel dependen (Ghozali, 2018:51)". Kekurangan dalam pemakaian koefisien determinasi ialah bias terhadap jumlah variable terikat. Oleh karenanya peneliti memakai nilai Adjusted $R^{2}$ sebagai instrumen penguji, sebab nilai ini dapat naik ataupun turun jika 1 variable bebas ditambahkan kedalam model. Karena. Berhubung variable bebas dalam penelitian ini lebih dari 2, maka Nilai Adjusted $R^{2}$ dipakai.

\section{ANALISA DAN PEMBAHASAN}

\subsection{Gambaran Umum Objek Penelitian}

PT.Visionet Data Internasional yaitu perusahaan total IT Managed Services di negara Indonesia. Didirikan tahun 2006, PT.Visionet Data International saat ini sudah disupport > 1300 personel di wilayah Negara Indonesia yang berada di 34 propinsi, 126 kota serta 155 titik diseluruh Indonesia. PT.Visionet Data International akan mendukung operasi IT di seluruh Indonesia dengan cara memanfaatkanstate-of-the-art teknologi. Perusahaan ini mengembangkan bisnis inti dengan cara memastikan hasil kerja yang maksimal, kompetensi \& skalabilitas sebagai customer. Melalui titik pelayanan nasional serta didukung penuh oleh contact center yang beroperasi selama 24 jam selama 7 hari penuh PT.Visionet Data International dapat membantu customer di manapun, kapanpun.

\subsection{Analisa Data}

\subsubsection{Uji Validitas dan Reliabilitas}

Didapatkan bahwa semua butir pernyataan pada variable Komunikasi dinyatakan Valid ini berdasarkan hasil hitung 
JRNAL ПММАH

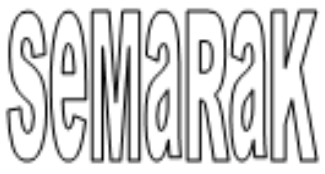

P-ISSN 2615-6849, E-ISSN 2622-3686

Jurnal Semarak,Vol.4,No.2,Juni 2021, Hal (105-118)

@Prodi Manajemen Fakultas Ekonomi Universitas Pamulang

menggunakan SPSS versi 25, hal itu ditunjukkan dengan nilai $\mathrm{r}_{\text {hitung }}$ lebih besar dari $\mathrm{r}_{\text {tabel }},(\mathrm{n}-2)=78-2=76$ yaitu 0,222 . Oleh karena itu data layak agar dilanjutkan sebagai data sebuah penelitian. Kemudian semua butir pernyataan pada variable gaya kepemimpinan dikatakan Valid, hal ini dibuktikan dengan nilai $r_{\text {hitung }}$ lebih besar dari $r_{\text {tabel }},(n-2)=78-2=$ 76 yaitu 0,222. Dengan begitu data layak dilanjutkan sebagai data penelitian. Diketahui bahwa Semua butir pernyataan dikatakan valid pada variable Kinerja Pegawai, hal itu dibuktikan dengan hasil $r_{\text {hitung }}$ lebih besar dari $\mathrm{r}_{\text {tabel}},(\mathrm{n}-2)=78-2=76$ yaitu 0,222 . Dengan demikian ini diteruskan sebagai data penelitian karena data sudah layak.

Reliabilitas yaitu sebuah indeks yang memperlihatkan sejauh mana suatu pekerjaan dapat dipercayai, instrumen yang valid umumnya pasti reliable. Berikut tabel hasil reliabilitas :

a. Variable Komunikasi $\left(\mathrm{X}_{1}\right)$

Table 2

Uji Reliabulitas Variable Komunikasi (X1)

Reliability Statistics

\begin{tabular}{cc} 
Cronbach's Alpha & N of Items \\
\hline .795 & 10 \\
\hline Sumber:SPSS versi 25 &
\end{tabular}

Dari tabel 2 tersebut diatas dapat diketahui bahwa variable komunikasi dikatakan reliable, karena $r_{\text {hitung }}>$ pada 0,60 adalah 0,795 >0,60 dikatakan reliable dengan syarat $\mathrm{N}=10$ taraf signifikan $5 \%$.

b. Variable Gaya Kepemimpinan (X2)

Tabel 3

Uji Reliabulitas Variable Gaya

Kepemimpinan (X2)

Reliability Statistics

\begin{tabular}{cc} 
Cronbach's Alpha & N of Items \\
\hline .848 & 10 \\
\hline Sumber:SPSS versi 25 &
\end{tabular}

Dari tabel 3 tersebut diatas dapat diketahui bahwa variable gaya kepemimpinan dikatakan reliable, karena $\mathrm{r}_{\text {hitung }}$ lebih besar dari pada 0,60 ialah 0,848
> 0,60 dikatakan reliable dengan syarat $\mathrm{N}=10$ dan $5 \%$ adalah taraf signifikannya.

c. Kinerja Karyawan (Y)

Table 4

Uji Reliabulitas Variable Kinerja Karyawan (Y)

Reliability Statistics

\begin{tabular}{cc} 
Cronbach's Alpha & N of Items \\
\hline .841 & 10 \\
\hline Sumber:SPSS versi 25 &
\end{tabular}

Variable kinerja karyawan dikatakan reliable, dengan melihat table 4 tersebut diatas, karena $r_{\text {hitung }}>$ pada 0,60 yaitu 0,841>0,60 dikatakan reliable dengan syatar $\mathrm{N}=10$ dan $5 \%$ adalah taraf signifikansinya.

\subsubsection{Hasil Uji Asumsi Klasik \\ 4.2.2.1 Uji Normalitas Data}

Hasil uji ditampilkan pada tabel berikut:

Tabel 5

\section{Hasil Uji Normalitas}

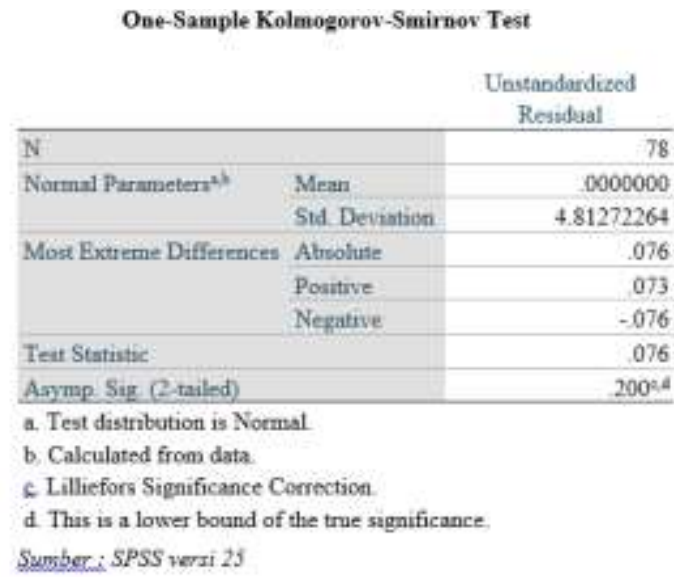

Nilai signifikan (Asymp. Sig. 2-tailed) adalah 0,200 dapat dilihat di table 5 tersebut diatas. Karena dikatakan signifikan apabila lebih dari $0,50(0,200>0,50)$ artinya data tersebut berdistribusi normal. 
JRNAL ПММАH

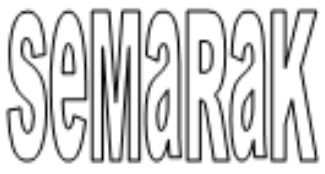

P-ISSN 2615-6849, E-ISSN 2622-3686

Jurnal Semarak,Vol.4,No.2,Juni 2021, Hal (105-118)

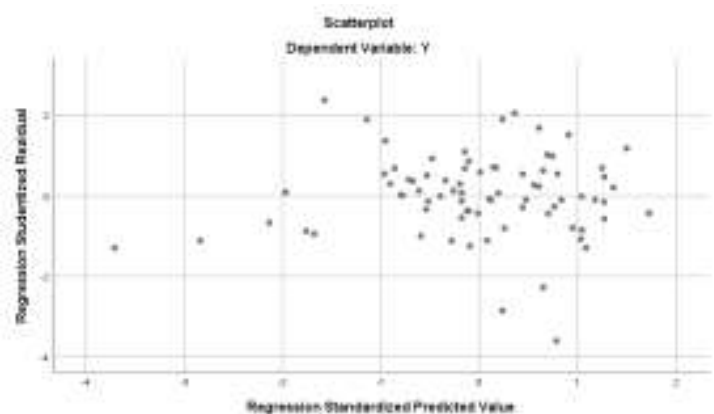

Normal P.P Plot of Regression Standardized Residual

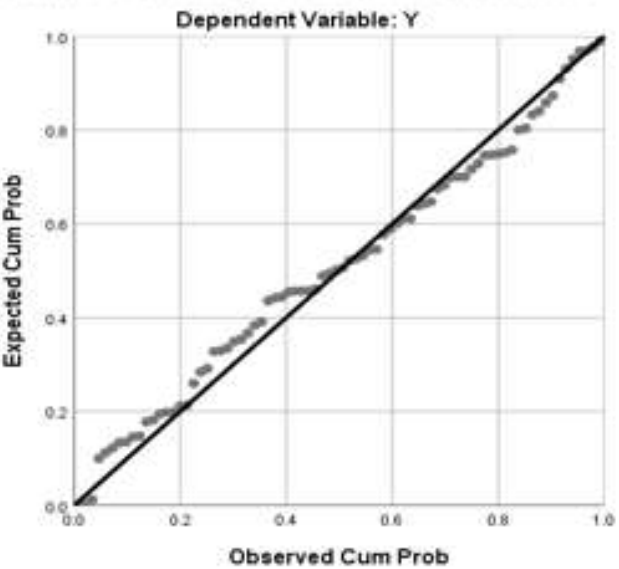

Gambar 2

Uji P-Plot Normalitas

Titik-titik telah menyebar sekitar garis \& mengikuti garis diagonal pada grafik tersebut diatas. Oleh sebab itu dapat dijelaskan bahwa data residu dari variable Komunikasi $\left(\mathrm{X}_{1}\right)$, Gaya Kepemimpinan $\left(\mathrm{X}_{2}\right)$, dan Kinerja Karyawan (Y) yang diteliti yaitu data yang berdistribusi normal.

\subsubsection{Uji Multikolinearitas}

Hasil Uji Multikolinearitas data dibawah ini:

Tabel 6

Uji Multikolonieritas

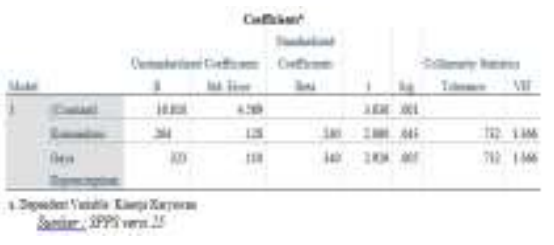

Nilai VIF < 10 dan nilai tolerance lebih besar dari 0,1 dapat dilihat dari table 6 diatas. Hal ini dapat diketahui dari besarnya nilai tolerance untuk variable Komunikasi dan Gaya Kepemimpinan tersebut, yaitu nilai tolerance diatas 0,1 , sedangkan untuk nilai VIF yaitu dibawah 10. Jadi dapat dikatakan bahwa variable bebas yang digunkan dalam penelitian ini tidak terjadi masalah multikolinieritas.

\subsubsection{Uji Heterokedastisitas}

Hasil dari pengujian dapat diketahui dalam gambar berikut ini:

\section{Gambar 3 Grafik Scatter Plot Hasil Uji Heterokedastisitas}

Titik-titik telah menyebar secara acak terlihat pada gambar 3 scatter plot diatas, maka dapat dikatakan bahwa tidak terjadi heterokedastisitas pada model regresi ini.

\subsubsection{Uji Autokorelasi}

Hasil uji ditampilkan pada tabel berikut:

\section{Tabel 7}

Uji Autokorelasi

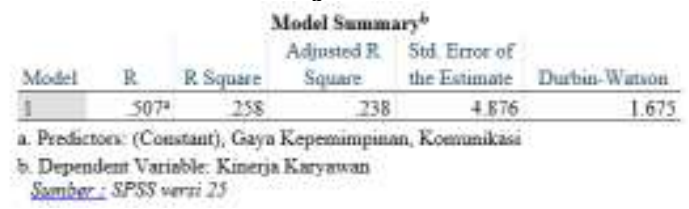

Nilai Durbin-Watson adalah sebesar 1,675 dapat dilihat dari table 7 diatas, dan ini termasuk dalam rentang $1,550-2,460$ dengan keterangan tidak ada autokorelasi. Dapat dikatakan bahwa data yang digunakan dalam penelitian ini tidak terjadi masalah autokorelasi.

\subsubsection{Hasil Analisa Regresi Berganda}

Hasil uji ditampilkan pada table berikut:

Table 8

Uji Regresi Linear Berganda 
JRNAL ПММАH

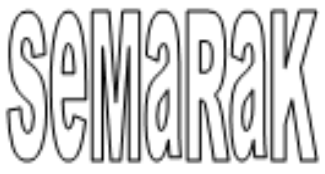

P-ISSN 2615-6849, E-ISSN 2622-3686

Jurnal Semarak,Vol.4,No.2,Juni 2021, Hal (105-118)

@Prodi Manajemen Fakultas Ekonomi Universitas Pamulang

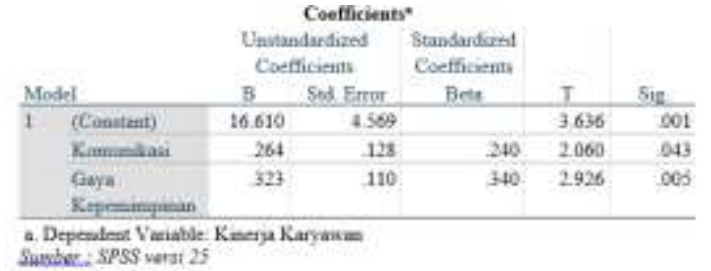

Persamaan regresi berganda berdasarkan pada table 8 diatas adalah sebagai berikut :

$Y=16,610+0,264 X_{1}+0,323 X_{2}$

Dalam persamaan tersebut dapat diambil ksimpulan bahwa :

1) Konstanta dengan nilai 16,610 artinya bahwa jika Komunikasi $\left(\mathrm{X}_{1}\right)$ dan Gaya Kepemimpinan $\left(\mathrm{X}_{2}\right)$ bernilai 0 , maka Kinierja Pehawai (Y) nilainya sebesar16,610.

2) Koefisien regresi Komunikasi $\left(X_{1}\right)$ dengan nilai 0,264 menjelaskan bahwa setiap penambahan $1 \%$ variabel Komunikasi $\left(\mathrm{X}_{1}\right)$ maka akan meningkatkan Kinerja Karyawan sebesar 0,264 dengan asumsi variable lain bernilai tetap.

3) Koefisien regresi Gaya Kepemimpinan $\left(X_{2}\right)$ dengan nilai 0,323 menjelaskan bahwa setiap penambahan $1 \%$ variabel Gaya Kepemimpinan $\left(\mathrm{X}_{2}\right)$ maka akan meningkatkan Kinerja Pegawai sebesar 0,323 dengan asumsi variable lain bernilai tetap.

\subsubsection{Hasil Uji Hipotesis}

\section{Hasil Uji t}

Table 9 dibawah ini menjelaskan hasil Uji t, sevagai berikut :

\section{Tabel 9}

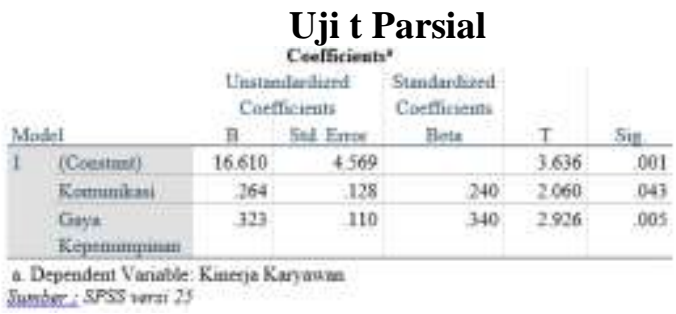

Kesimpulan:

Menurut table 9 tersebut diatas diperoleh nilai $t_{\text {hitung }}$ variabel komunikasi adalah sebesar 2,060 sedangkan nilai $t_{\text {tabel }}$ untuk $\mathrm{n}=78-3=75$, maka sebesar 1,665. Komunikasi secara parsial berpengaruh signfikan terhadap kinerja karyawan karena $t_{\text {hitung }}>t_{\text {tabel }}(2,060>1,665)$ dan hasil signifikan $<0,05(0,04<0,05)$.

Dapat disimpulkan bahwa gaya kepemimpinan secara parsial berpengaruh signfikan terhadap kinerja karyawan, hal ini karena nilai thitung variabel gaya kepemimpinan yaitu dengan nilai 2,926 sedangkan nilai $t_{\text {hitung }}$ untuk $\mathrm{n}=78-3=75$, maka sebesar 1,665. Karena $t_{\text {hitung }}>t_{\text {tabel }}(2,926>1,665)$ dan nilai signifikan $<0,05(0,00<0,05)$.

\section{Hasil Uji Goodness of Fit (Uji F dan $\mathbf{R}^{2}$ )}

\section{A. Hasil Uji F (Uji Simultan)}

Table 10 dibawah ini menjelaskan hasil Uji F sebagai berikut :

\section{Tabel 10}

\section{Uji F Simultan}

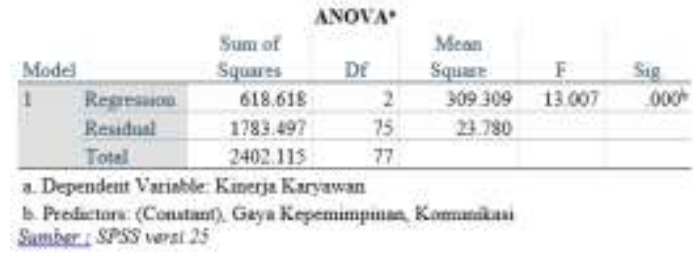

Menurut table 10 diatas dapat dikatakan bahwa secara simultan komunikasi dan gaya kepemimpinan secara simultan berpengaruh signifikan terhadap kinerja karyawan PT Visionet Data Internasional Cabang Karawaci karena menurut table 10 di atas diketahui nilai $F_{\text {hitung }}$ 13,007 lebih besar dari $F_{\text {tabel }}$ 3,12 dengan signifikan 0,00 lebih kecil dari 0,05 atau $\left(\mathrm{F}_{\text {hitung }}\right.$ $\left.>\mathrm{F}_{\text {tabel }}\right)\left(\mathrm{F}_{\text {signifikan }}<0,05\right)$.

B. Perhitungan Koefisien Determinasi $\left(\mathrm{R}^{2}\right)$

Table 11 dibawah I I menjelaskan hasil perhitungan koefisien determinasi sebagai berikut:

Tabel 11

Uji Koefisien Determinasi

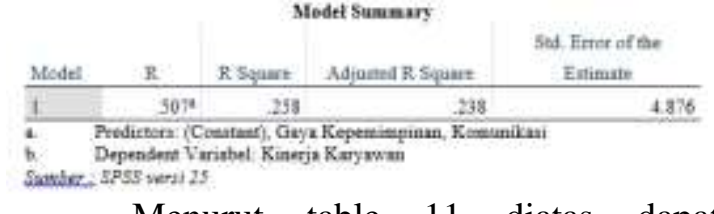

Menurut table 11 diatas dapat dikatakan bahwa Komunikasi dan gaya kepemimpinan mempengaruhi kinerja pegawai 
JRNAL ПMПAH

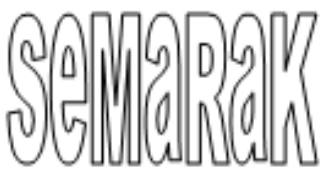

P-ISSN 2615-6849, E-ISSN 2622-3686

Jurnal Semarak,Vol.4,No.2,Juni 2021, Hal (105-118)

@Prodi Manajemen Fakultas Ekonomi Universitas Pamulang

senilai $25,8 \%$ sedangkan sisanya sebesar $74,2 \%$ dipengaruhi faktor lain yang tidak digunakan dalam penelitian ini, karena menurut table 11 di atas dapat diketahui bahwa nilai $R$-Square $\left(\mathrm{r}^{2}\right)$ sebesar 0,258 atau $25,8 \%$.

\subsection{Pembahasan}

Hasil yang diperoleh dari hasil uji statistik $t$ yang menguji secara sebagian pengaruh dari masing-masing variable bebas, dan hasil uji statistik $F$ yang menguji secara bersama-sama pengaruh variable bebas terhadap variable terikat. Maka hasil tersebut dapat dijelaskan sebagai berikut:

1. Pengaruh Komunikasi $\left(X_{1}\right)$ Terhadap Kinerja Karyawan (Y) pada PT.Visionet Data Internasional Cabang Karawaci

Berdasarkan hasil pengujian hipotesis secara sebagian (uji t) didapatkan nilai $t_{\text {hitung }}$ dengan nilai 2,060 dan nilai signifikan senilai 0,04 , sedangkan nilai tabel adalah 1,656. Dapat dikatakan bahwa komunikasi secara sebagian berpengaruh signifikan terhadap kinerja pegawai karena $t_{\text {hitung }}>$ $\mathrm{t}_{\text {tabel }}(2,060>1,656)$ dan nilai signifikan $<0,05(0,04<0,05)$.

2. Pengaruh Gaya Kepemimpinan $\left(\mathbf{X}_{2}\right)$ Terhadap Kinerja Pegawai (Y) pada PT.Visionet Data Internasional Cabang Karawaci

Berdasarkan hasil pengujian hipotesis secara sebagian (uji t) didapatkan nilai $\mathrm{t}_{\text {hitung }}$ senilai 2,926 dan nilai signifikan senilai 0,00 , sedangkan nilai $t_{\text {tabel }}$ adalah 1,656. Karena $t_{\text {hitung }}>t_{\text {tabel }}(2,926>$ $1,656)$ dan nilai signifikan $<0,05(0,00$ $<0,05)$, maka dapat dikatakan bahwa gaya kepemimpinan secara seabgian berpengaruh signifikan terhadap kinerja karyawan.

3. Pengaruh Komunikasi $\left(\mathrm{X}_{1}\right)$ dan Gaya Kepemimpinan $\left(\mathbf{X}_{2}\right)$ Terhadap Kinerja Karyawan (Y) pada PT.Visionet Data Internasional Cabang Karawaci
Berdasarkan hasil pengujian hipotesis secara bersama-sama (uji f) didapatkan nilai $f_{\text {hitung }}$ senilai 13,007 dan nilai signifikan sebesar 0,040 sedangkan nilai $\mathrm{f}_{\text {tabel }}$ pada tingkat kepercayaan adalah 3,12 . Karena $f_{\text {hitung }}>f_{\text {tabel }}(13,007>3,12)$ dan nilai signifikan $<0,05(0,00<0,05)$, jadi dapat dikatakan bahwa variabel komunikasi dan gaya kepemimpinan berpengaruh signifikan terhadap kinerja karyawan.

\section{PENUTUP}

\subsection{Kesimpulan}

Dengan mengetahui dari hasil penelitian yang sudah dilakukan oleh peneliti, maka peneliti akan memberikan hasil kesimpulan sebagai berikut :

1. Berdasarkan hasil nilai uji parsial (Uji T) menjelaskan bahwa komunikasi berpengaruh signfikan terhadap Kinerja Pegawai.

2. Berdasarkan hasil nilai uji parsial (Uji T) menjelaskan bahwa Gaya Kepemimpinan berpengaruh signfikan terhadap Kinerja Pegawai

3. Berdasarkan hasil nilai uji simultan (Uji F) menyatakan bahwa Komunikasi dan Gaya Kepemimpinan secara bersamasama berpengaruh signifikan terhadap Kinerja Karyawan. Berdasarkan uji determinasi (R2) disimpulkan bahwa komunikasi dan gaya kepemimpinan mempengaruhi Kinerja Pegawai sebesar 25,8\% sementara sisanya sebesar $74,2 \%$ dipengaruhi faktor lain yang tidak digunakan dalam penelitian ini.

\subsection{Saran}

Berdasarkan kesimpulan hasil penelitian tentang pengaruh komunikasi \& gaya kepemimpinan terhadap kinerja pegawai di PT.Visionet Data Internasional Cabang Karawaci maka peneliti akan mengemukakan beberapa saran yang dapat dijadikan solusi dari pembahasan. Berikut dibawah ini adalah 
JRNAL ПMПAH

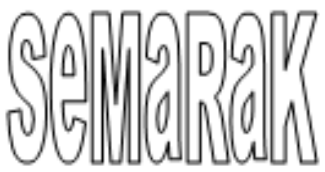

P-ISSN 2615-6849, E-ISSN 2622-3686

Jurnal Semarak,Vol.4,No.2,Juni 2021, Hal (105-118)

@Prodi Manajemen Fakultas Ekonomi Universitas Pamulang

beberapa saran yang akan peneliti sampaikan adalah sebagai berikut :

1. Berdasarkan hasil perolehan penelitian yang sudah dilakukan menjelaskan bahwa komunikasi mempunyai pengaruh terhadap kinerja karyawan secara langsung, oleh karena itu penulis ingin memberikan saran yang dapat dijadikan sebagai bahan pertimbangan dalam hal meningkatkan kinerja pegawai. Saran yang peneliti berikan adalah terkait dengan peningkatan kinerja pegawainya adalah melalui komunikasi yang baik. Karyawan berkomunikasi aktif baik secara langsung maupun tidak langsung (melalui WA grup), yang mempunyai ratarata skor yang masih rendah. Saran dari penulis adalah "komunikasi yang dilakukan baik komunikasi ke atas, bawah, maupun horizontal semuanya agar dilakukan dengan dasar rasa saling percaya antara masingmasing individu yang sedang berkomunikasi. Pimpinan hendaknya mampu merangkul setiap karyawan, memahami setiap kebutuhannya serta mampu menjadi pengayom". Memberikan saran kepada pegawai untuk bekerja dalam tim yang kompak dan harmonis. Saling menghormati adanya perbedaan pendapat dan keyakinan, menghargai setiap perbedaan tersebut untuk tujuan lebih baik. Perusahaan perlu lebih memerhatikan karyawan menyelesaikan pekerjaan dan tanggung jawab dalam bekerja, agar karyawan lebih bertanggung jawab dalam menyelesaikan pekerjaan dengan tepat waktu.

2. Peneliti hanya meneliti komunikasi \& gaya kepemimpinan yang mempengaruhi kinerja didalam melakukan penelitian ini, jadi sebetulnya masih terdapat banyak faktor lain yang secara teoritis dapat mempengaruhi kinerja karyawan. Oleh karena itu, perlu adanya kajian lebih lanjut terhadap faktorfaktor lain yang dapat mempengaruhi kinerja karyawan yang tidak diteliti oleh penulis. Mengembangkan lagi penelitian ini dengan mempertimbangkan variable-variable lain seperti turnover karyawan dan iklim organisasi yang mungkin memiliki pengaruh yang lebih besar terhadap kinerja pegawai dan dapat berpengaruh terhadap komunikasi dan kinerja karyawan merupakan salah satu Saran yang akan penulis berikan untuk penelitian selanjutnya.

\section{DAFTAR PUSTAKA}

Ading, S. (2020). "PENGARUH GAYA KEPEMIMPINAN, MOTIVASI, SERTA DISIPLIN KERJA TERHADAP KINERJA KARYAWAN (Study di PT Mitsui Leasing Capital Indonesia Abdul Muis-Jakarta Pusat)." KREATIF: Jurnal Ilmiah Prodi Manajemen Universitas Pamulang, 8(1), 18-38.

Akhmad Subkhi dan Moh. Jauhar, 2013, "Pengantar Teori dan Perilaku Organisasi", Jakarta : Prestasi Pustaka

Bernardin and Russel. (2014). Human Resource Management. New Jersey: International Editions Upper Saddle River, Prentice Hall.(2012). Metode Penelitian Kuantitatif, Kualitatif, Dan Kombinasi (Mixed Methods). Jakarta: PT. Bumi Aksara.

Edison. (2016). "Manajemen Sumber Daya Manusia". Bandung: Alfabeta.

Fahmi, I. (2010). Manajemen Resiko. Bandung: Alfabeta.

Ghozali, Imam. (2016). Aplikasi Analisis Multivariete dengan Program IBM SPSS 23. Semarang: Badan Penerbit Universitas Diponegoro.

Handoko, T. H. (2016). "Manajemen Edisi 2" . Yogyakarta : BPFE Yogyakarta . 
JRNAL ПMПAH

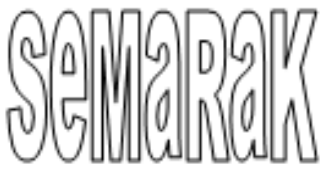

P-ISSN 2615-6849, E-ISSN 2622-3686

Jurnal Semarak,Vol.4,No.2,Juni 2021, Hal (105-118)
Krisnaldy, K., Pasaribu, V. L. D., \& Senen, S. (2019). Pengaruh Budaya Organisasi, Lingkungan Kerja Dan Iklim Organisasi Terhadap Motivasi Pegawai Serta Dampaknya Terhadap Kepuasan Semarak, 2(2), 164-183.

Krisnaldy, K., Pasaribu, V. L. D., \& Batubara, A. S. (2020). Analisis Pengaruh Kedisiplinan Terhadap Performa Pegawai Kelurahan Rempoa, Kota Tangerang Selatan. Jurnal Mandiri: Ilmu Pengetahuan, Seni, Dan Teknologi, 4(2), 131-138.

Mangkunegara, A. A. (2015 ). "Manajemen Sumber Daya Manusia”. Bandung : PT Remaja Rosdakarya .

Mulyana, D. (2010). "Imu Komunikasi : Suatu Pengantar". Bandung: Remaja Rosdakarya.

Nurjaman, K. d. (2012). "Komunikasi \& Public Relations". Bandung: CV Pustaka Setia.

Pasaribu, V. L. D., \& Krisnaldy, K. (2018). ANALISIS KEPUASAN JAMA'AH PADA KINERJA DEWAN KEMAKMURAN MASJID ALHIDAYAH PERIODE TAHUN 2017. KREATIF: Jurnal Ilmiah Prodi Manajemen Universitas Pamulang, 6(4), 41-51.

Pasaribu, V. L. D., Krisnaldy, K., \& Warasto, H. N. (2020). Pengaruh Gaya Kepemimpinan, Disiplin Kerja Dan Kompensasi Terhadap Kinerja Pegawai (Studi kasus kelurahan Pisangan Ciputat). Jurnal Disrupsi Bisnis: Jurnal Ilmiah Prodi Manajemen, Fakultas Ekonomi, Universitas Pamulang, 3(1).
Pasaribu, V. L. D., \& Yanuarso, B. P. (2021). PENGARUH STRES KERJA DAN DISIPLIN KERJA TERHADAP KINERJA KARYAWAN PADA PT. MULTRITRAN ABADI SRENGSENG JAKARTA BARAT PERIODE 2018. Jurnal Sekretari Universitas Pamulang, 8(1), 60-72.

Siagian, S. P. (2016). "Manajemen Sumber Daya Manusia". Jakarata: Bumi Aksara.

Sugiyono. (2015). "Metode Penelitian Bisnis". Bandung: Alfabeta.

Sugiyono. (2017). "Metode Penelitian Pendidikan: Pendekatan Kuantitatif. Kualitatif dan $R \& D$ ”. Bandung : Alfabeta

Sunarto, A. (2020). "Pengembangan Sumber Daya Manusia dengan Berbasis Inovasi Untuk Menghadapi Revolusi Industri 4.0”. Jurnal Ilmiah MEA (Manajemen, Ekonomi, \& Akuntansi), 4(2), 397 407.

Sunarto, A. (2020). "Kinerja Karyawan Berbasis Kepemimpinan Dan Motivasi Pada PT. Duta Jaya Putra Persada Mining”. JENIUS (Jurnal Ilmiah Manajemen Sumber Daya Manusia), 3(3), 246-257.

Sunarto, A. (2019). "Analisis Kinerja Karyawan Pada PT. Bank Mandiri Cluster Cilegon I". SCIENTIFIC JOURNAL OF REFLECTION: Economic, Accounting, Management and Business, 2(3), 241-250.

Sunarto, A., Tanjung, A. W., \& Ellesia, N. (2020). "Teacher Performance Based on The Visionary Leadership 
Style of School, Competency and Work Discipline (Study at Muhammadiyah Setiabudi Pamulang College)". Journal of Research in Business, Economics, and Education, 2(5), 1046-1052.

Sunarto, A. (2020). KINERJA PEGAWAI BERBASIS KEPEMIMPINAN DAN LINGKUNGAN KERJA PADA PT VICTORY CHINGLUH INDONESIA DIVISI QUALITY. KREATIF: Jurnal Ilmiah Prodi Manajemen Universitas Pamulang, 8(2), 92101.

Sunarto, A., Qurbani, D., \& Virby, S. (2020). Pengaruh Kompetensi, Disiplin Kerja Dan Lingkungan Kerja Terhadap Kinerja Pada PT Anugrah Bersama Sejahtera Depok. JIMF (Jurnal Ilmiah Manajemen Forkamma), 4(1).

Sutrisno. (2014). “Manajemen Sumber Daya Manusia" . Jakarta : Kencana Prenada Media Group .

Widodo, S. E. (2015). "Manajemen Pengembangan Sumber Daya Manusia”. Yogyakarta: Pustaka Pelajar. 